\title{
ANALISIS PEMILIHAN METODE PENGASUTAN MOTOR INDUKSI 3 FASA SEBAGAI PENGGERAK POMPA PENGENDALI BANJIR BANDARA AHMAD YANI MENGGUNAKAN SOFTWARE ETAP 12.6
}

\author{
Jibril Malemba*), Karnoto dan Tejo Sukmadi \\ Departemen Teknik Elektro, Universitas Diponegoro \\ Jl. Prof. Sudharto, SH, Kampus UNDIP Tembalang, Semarang 50275, Indonesia \\ ${ }^{*}$ E-mail: jibril.mudjtabar@gmail.com
}

\begin{abstract}
Abstrak
Pompa yang digunakan pada sistem drainase Bandara Ahmad Yani digerakkan motor induksi 3 fasa. Motor induksi dipilih karena harganya relatif murah, konstruksi kokoh, dan mudah melakukan perawatannya. Perlu diperhatikan arus pengasutannya memiliki nilai 5-7 kali lebih besar dari arus nominalnya. Besarnya arus saat pengasutan dapat menyebabkan tegangan jatuh dan menganggu operasi dari peralatan lain. Arus yang besar juga menghasilkan panas berlebih yang dapat merusak insulasi kumparan, hal ini dapat memperpendek umur mesin. Untuk mengurangi arus pengasutan yang besar maka diperlukan metode pengasutan yang berfungsi untuk mereduksi tegangan. Pada penelitian ini dilakukan analisis dari beberapa metode pengasutan yang digunakan, yaitu $D O L$, bintang-delta, autotransformator, dan softstarter. Berdasarkan simulasi menggunakan ETAP 12.6. Pada motor berdaya 3,1 KW yang memiliki tegangan jatuh paling besar pada pengasutan $D O L$ sebesar $17,72 \%$ dan terendah pada pengasutan softstarter sebesar $9,35 \%$. Untuk motor berdaya $130 \mathrm{KW}$ tegangan jatuh paling besar pada pengasutan $D O L$ sebesar $12,81 \%$ dan terendah pada pengasutan softstarter sebesar $9,35 \%$. Untuk motor berdaya $450 \mathrm{KW}$ tegangan jatuh paling besar pada pengasutan $D O L$ sebesar $12,41 \%$ dan terendah pada pengasutan softstarter sebesar $8,79 \%$. Untuk metode pengasutan yang direkomendasikan adalah metode bintang-delta, dikarenakan motor tidak bekerja setiap saat, dan biaya investasi pengasutan bintang-delta tidak begitu besar dibanding metode lainnya.
\end{abstract}

Kata kunci: Motor Induksi, Metode Pengasutan, ETAP 12.6

\begin{abstract}
The pump used in Ahmad Yani Airport drainage system driven by 3 phase induction motor. Induction motor are chosen because the price relatively cheap, sturdy construction, and easy to maintain. It should be noted the starting current about 5-7 times from its nominal. The starting current can cause voltage drop and disrupt the operation other equipment. Large currents can generate excessive heat which can damage coil insulation. To reducestarting current, it's necessary to have a starting method to reduce starting voltage. In this paper are analyzed some starting methods used, DOL, star-delta, autotransformer, and softstarter. Based on the ETAP simulation on $3.1 \mathrm{KW}$ motor which has the highest voltage drop is found on DOL starting was $17.72 \%$ and the lowest in softstarter starting was $9.35 \%$. On $130 \mathrm{KW}$ which has the highest voltage drop is found on DOL starting was $12.28 \%$ and the lowest in softstarter starting was $9.35 \%$. For $450 \mathrm{KW}$ motor which has the highest voltage drop is found on DOL starting was $12.41 \%$ and the lowest in softstarter starting was $8.79 \%$. For the recommended starting method is the star-delta, because the motor doesn't work all times, and investment cost of star-delta starting method isn't so large compared to others.
\end{abstract}

Keywords: Induction Motor, Starting Method, ETAP 12.6

\section{Pendahuluan}

Kota Semarang membutuhkan transportasi massal yang harus segera terpenuhi salah satunya adalah pesawat terbang. Oleh karena adanya kebutuhan tersebut, pemerintah Kota Semarang berusaha untuk memenuhinya dengan pembangunan terminal baru untuk Bandara Ahmad Yani Semarang. Bandara yang baik harus dilengkapi dengan fasilitas keselamatan dan keamanan penerbangan, fasilitas utama, dan fasilitas penunjang lainnya. Fasilitas keselamatan dan keamanan bandara salah satunya yaitu sistem drainase bandara. Area bandara perlu penyerapan air yang cepat, sehingga membutuhkan sistem drainase yang terintegrasi. Area runway, taxiway, dan apron harus bebas dari genangan air yang bertujuan untuk keselamatan penerbangan.

Dalam sistem drainase yang baik diperlukan pompa air yang dapat diandalkan. Dari sisi penggerak pompa motor induksi 3 fasa menjadi pilihan dibandingkan motor listrik lainnya. Hal ini dikarenakan harganya yang relatif lebih 
murah, konstruksi yang kokoh, mudah dalam melakukan perawatan, dan dapat diproduksi berdasarkan kebutuhan yang diinginkan[1]. Perlu diperhatikan dalam pengoperasian motor induksi 3 fasa tentang arus pengasutannya yang memiliki nilai 5-7 kali lebih besar dari arus nominalnya dan torsi awal bisa 2 kali lebih besar dari nilai nominalnya. Besarnya arus saat pengasutan dapat menyebabkan voltage drop dan menganggu operasi dari peralatan lainnya yang bekerja pada jaringan yang sama. Arus yang besar juga dapat menghasilkan panas berlebih yang dapat merusak insulasi kumparan, hal ini dapat memperpendek umur mesin[2].

Cara untuk menrunkan arus pengasutan yang besar dan pemakaian energi listrik oleh motor induksi adalah dengan menggunakan peralatan pengasutan tertentu, yang bertujuan agar saat pengasutan tidak langsung dihubungkan dengan tegangan penuh[3]. Metode ini dikenal sebagai metode pengasutan dengan tegangan diturunkan (reduced voltage starting). Metode tersebut antara lain metode reaktor, metode autotransformator, metode resistor, metode bintang-delta, metode soft starter, dan metode variable frekuensi [3][4][5].

Pada penelitian ini akan dilakukan analisa dari metode pengasutan Direct On Line (DOL), Bintang-Delta (Y-D), Autotransformator, dan Soft Starting menggunakan sotware ETAP 12.6 pada mode Motor Acceleration Analysis untuk mengetahui besarnya arus pengasutan pada masing-masing metode. Selain itu keempat metode tersebut juga akan dilakukan analisa dari segi ekonoms berupa nilai investasi yang diperlukan dalam pengadaan peralatn yang mendukung, dan juga konsumsi energi listrik yang dibutuhkan saat pengasutan. Dari hasil analisa tersebut nantinya dapat disimpulkan manakah metode terbaik dari segi teknis dan memberikan anggaran biaya sebagai pembanding dari segi ekonominya.

\section{Metode}

\subsection{Langkah Penelitian}

Metode penelitian dari penelitian ini diperlihatkan pada gambar 1. Penelitian dimulai dengan mengumpulkan data yang dibutuhkan, seperti kapasitas debit total air yang perlu dipindahkan, dan denah rumah pompa. Kemudian melakukan perancangan variasi jumlah pompa dari sistem pompa drainase, dan juga memilih pompa yang akan digunakan pada sistem drainase tersebut. Langkah berikutnya adalah membuat single line diagram dari kelistrikan sistem pengendali banjir secara keseluruhan. Untuk melakukan simulasi perbandingan dimasukan dahulu pengaturan parameter pada metode pengasutan yang digunakan, setelah itu menjalankan simulasi motor acceleration analysis pada software ETAP. Dari hasil simulasi tersebut kemudian dibandingkan dengan standar yang digunakan, yaitu IEEE P3002.7/D9 apakah tegangan jatuh masih sesuai dengan standar atau tidak, apabila tidak sesuai makan perlu dilakukan pengaturan parameter pengasutan ulang. Jika sesuai dengan standar maka hasil simulasi akan dianalisis.

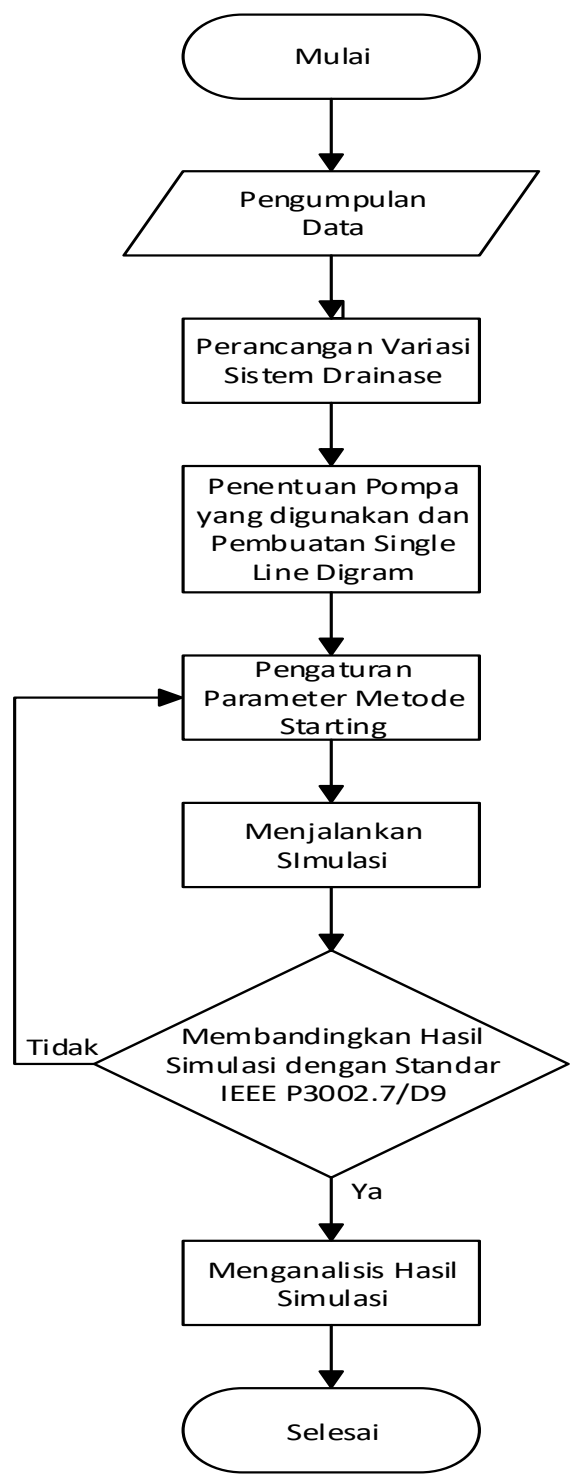

Gambar 1. Diagram alir penelitian.

\subsection{Data Penelitian}

Dari data yang diperoleh kapasitas total debit air yang mampu dialirkan dalam sistem drainase, sebesar $6 \mathrm{~m}^{3} / \mathrm{s}$. Pada penelitian ini dibuat menjadi dua variasi jumlah pompa yang pertama menggunakan 6 buah pompa berkapasitas $1 \mathrm{~m}^{3} / \mathrm{s}$ dan sebuah pompa cadangan dengan kapasitas debit yang sama, untuk variasi kedua menggunkan 2 buah pompa berkapasitas $2 \mathrm{~m}^{3} / \mathrm{s}$ ditambah 2 buah pompa berkapasitas $1 \mathrm{~m}^{3} / \mathrm{s}$ dan sebuah pompa cadangan dengan kapasitas yang $1 \mathrm{~m}^{3} / \mathrm{s}$. Dalam sistem drainase ini terdapat pula subsistem air baku dan Reverse Osmosis (RO), yang membutuhkan 3 buah pompa untuk subsistem air baku, 2 buah pompa untuk subsistem $R O$, pompa yang digunakan memiliki kapasitas $0,02 \mathrm{~m}^{3} / \mathrm{s}$. 
Untuk semua pompa yang digunakan memiliki jenis submersible. Pada pompa air baku dan RO memakai merk Xylem dengan daya 3,1 KW untuk spesifikasinya dapat dilihat pada tabel 1 berikut:

Tabel 1. Spesifikasi motor pompa kapasitas $0,02 \mathrm{~m}^{3} / \mathrm{s}$.

\begin{tabular}{cc}
\hline Spesifikasi & Nilai \\
\hline Daya motor & $3,1 \mathrm{KW}$ \\
Frekuensi & $50 \mathrm{~Hz}$ \\
Tegangan Kerja & $380 \mathrm{~V}$ \\
Arus & $6,8 \mathrm{~A}$ \\
Jumlah Kutub & 4 \\
Kecepatan & $1445 \mathrm{RPM}$ \\
Efisiensi motor & $84,1 \%$ saat beban penuh \\
& $85,1 \%$ saat $3 / 4$ beban \\
& $84,1 \%$ saat $1 / 2$ beban \\
Faktor Daya & 0,83 saat beban penuh \\
& 0,77 saat $3 / 4$ beban \\
Inersia Motor & 0,66 saat $1 / 2$ beban \\
\end{tabular}

Sedangkan pompa drainase menggunakan merk Grundfos, untuk pompa yang berkapasitas debit $1 \mathrm{~m}^{3} / \mathrm{s}$ memiliki daya $130 \mathrm{KW}$ dengan spesifikasi dapat dilihat pada tabel 2.

Tabel 2. Spesifikasi motor pompa kapasitas $1 \mathrm{~m}^{3} / \mathrm{s}$.

\begin{tabular}{cc}
\hline Spesifikasi & Nilai \\
\hline Daya motor & $130 \mathrm{KW}$ \\
Frekuensi & $50 \mathrm{~Hz}$ \\
Tegangan Kerja & $380 \mathrm{~V}$ \\
Arus & $288 \mathrm{~A}$ \\
Jumlah Kutub & 12 \\
Kecepatan & $495 \mathrm{RPM}$ \\
Efisiensi motor & $92 \%$ saat beban penuh \\
& $92 \%$ saat $3 / 4$ beban \\
& $91 \%$ saat $1 / 2$ beban \\
Faktor Daya & 0,71 saat beban penuh \\
& 0,64 saat $3 / 4$ beban \\
& 0,51 saat $1 / 2$ beban \\
Inersia Motor & $28,6 \mathrm{kgm}^{2}$ \\
\hline
\end{tabular}

Pompa yang berkapasitas debit $2 \mathrm{~m}^{3} / \mathrm{s}$ memiliki daya 450 KW dengan spesifikasi dapat dilihat pada tabel 3.

Tabel 3. Spesifikasi motor pompa kapasitas $2 \mathrm{~m}^{3} / \mathrm{s}$.

\begin{tabular}{cc}
\hline Spesifikasi & Nilai \\
\hline Daya motor & $450 \mathrm{KW}$ \\
Frekuensi & $50 \mathrm{~Hz}$ \\
Tegangan Kerja & $380 \mathrm{~V}$ \\
Arus & $837 \mathrm{~A}$ \\
Jumlah Kutub & 8 \\
Kecepatan & $743 \mathrm{RPM}$ \\
Efisiensi motor & $95 \%$ saat beban penuh \\
& $95 \%$ saat $3 / 4$ beban \\
& $95 \%$ saat $1 / 2$ beban \\
Faktor Daya & 0,82 saat beban penuh \\
& 0,77 saat $3 / 4$ beban \\
Inersia Motor & 0,68 saat $1 / 2$ beban \\
\end{tabular}

Untuk merancang single line diagram (SLD) perlu mengetahui beban yang dipakai, bukan hanya pompa tetapi terdapat juga Overhead Crane $(\mathrm{OHC})$ untuk memindahkan pompa saat pemasangan dan perawatan dan beban statis berupa lampu untuk penerangan rumah pompa. Untuk suplai energinya menggunakan grid PLN sebagai suplai energi utama dan generator sebagai suplai cadangan. Dapat dilihat $S L D$ kedua variasi sebagai berikut:

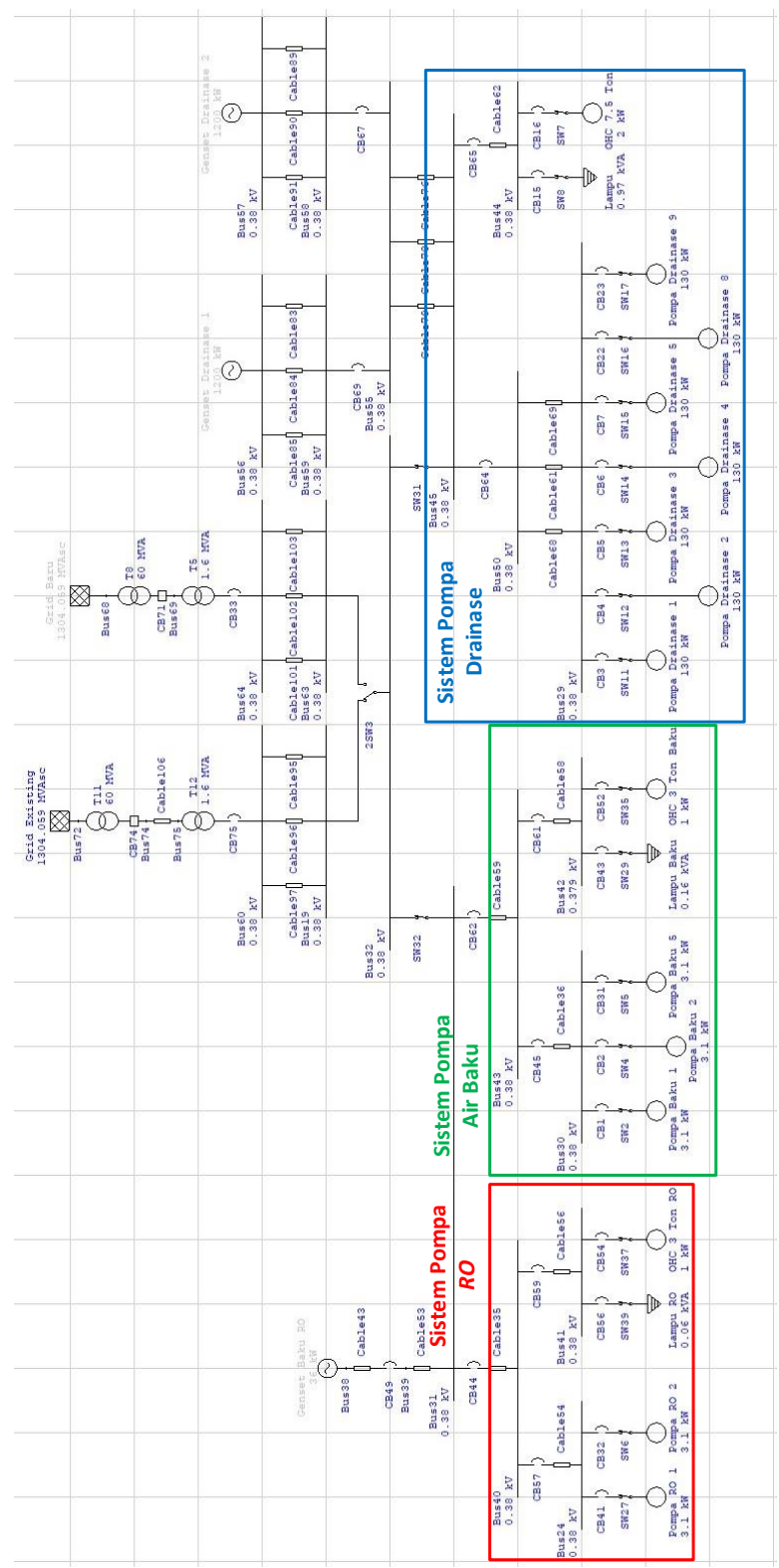

Gambar 2. Single line diagram variasi 1

Pada variasi 1 daya total yang dibutuhkan untuk pompa $R O$ sebesar 6,2 KW, pompa air baku sebesar 9,6 KW, dan pompa drainase sebesar $910 \mathrm{KW}$. Kebutuhan daya untuk beban lampu pada rumah pompa $R O$ sebesar 0,06 KVA, rumah pompa air baku sebesar 0,16 KVA, dan rumah drainase sebesar 0,97 KVA. Untuk beban OHC disesuaikan oleh berat dari masing-masing pompa, pada rumah pompa air baku dan $R O$ menggunakan $O H C$ dengan kapasitas angkut sebesar 3 ton, yang membutuhkan daya sebesar $1 \mathrm{KW}$, sedangkan untuk rumah pompa drainase 
dipasang $\mathrm{OHC}$ dengan kapasitas angkut 7,5 ton yang membutuhkan daya sebesar $2 \mathrm{KW}$. Generator yang dipakai sebagai suplai energi cadangan memiliki kapasitas $36 \mathrm{KW}$ untuk suplai energi pada rumah pompa air baku dan $R O$, sedangkan untuk rumah pompa drainase digunakan dua buah generator dengan kapasitas masing-masing generator sebesar 1,2 MW.

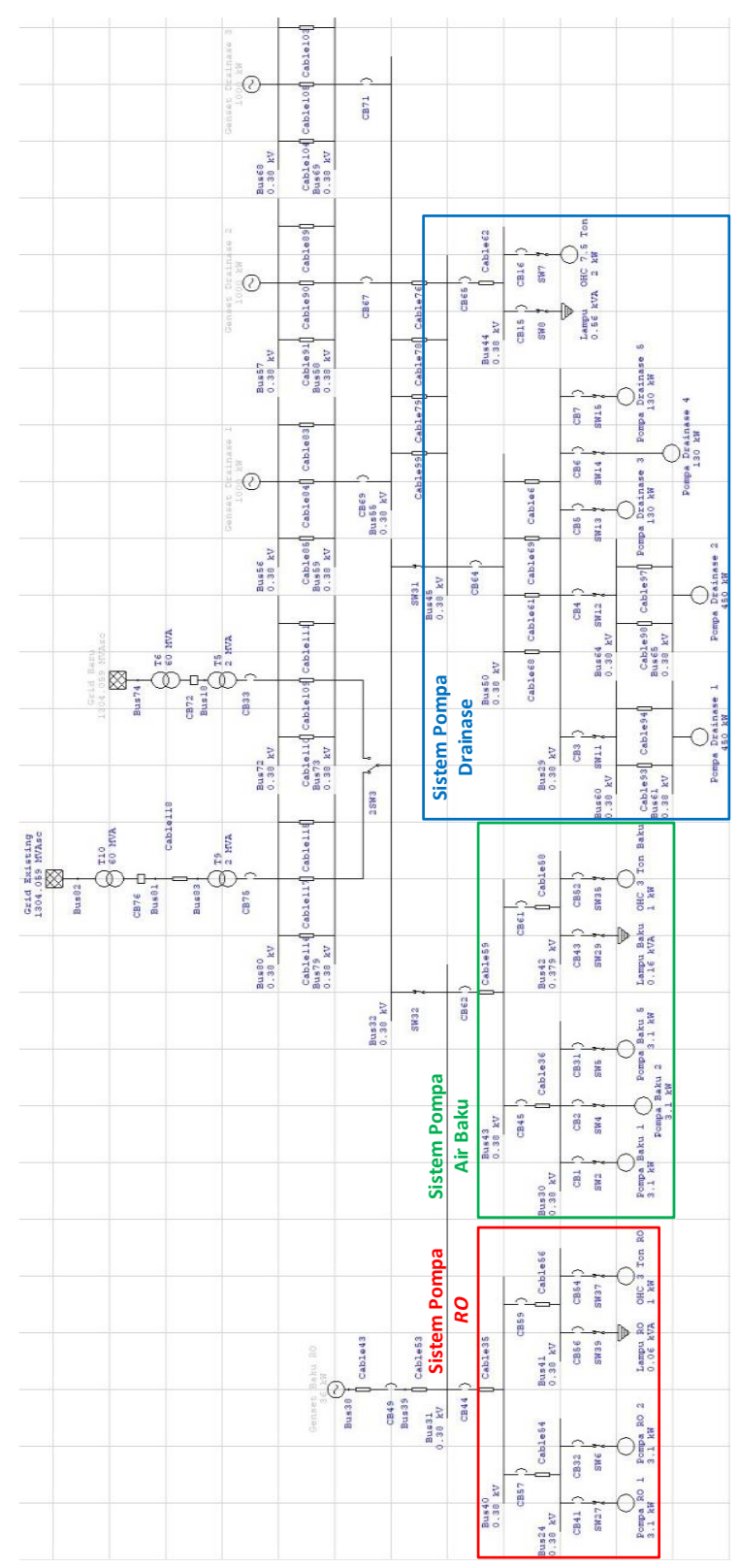

Gambar 3. Single line diagram variasi 2

Untuk variasi 2 daya total yang dibutuhkan untuk pompa air baku sebesar 9,6 KW, pompa RO sebesar 6,2 KW, dan pompa drainase sebesar 1,29 MW. Kebutuhan daya untuk beban lampu pada rumah pompa RO sebesar 0,06 KVA, rumah pompa air baku sebesar $0,16 \mathrm{KVA}$, dan rumah drainase sebesar 0,56 KVA. Untuk beban OHC disesuaikan oleh berat dari masing-masing pompa, pada rumah pompa air baku dan $\mathrm{RO}$ menggunakan $\mathrm{OHC}$ dengan kapasitas angkut sebesar 3 ton, yang membutuhkan daya sebesar $1 \mathrm{KW}$, sedangkan untuk rumah pompa drainase dipasang OHC dengan kapasitas angkut 7,5 ton yang membutuhkan daya sebesar $2 \mathrm{KW}$. Generator yang dipakai sebagai suplai energi cadangan memiliki kapasitas $36 \mathrm{KW}$ untuk suplai energi pada rumah pompa air baku dan RO, sedangkan untuk rumah pompa drainase digunakan tiga buah generator dengan kapasitas masing-masing generator sebesar $1 \mathrm{MW}$.

\section{Hasil dan Analisis \\ 3.1. Pengasutan Direct OnLine}

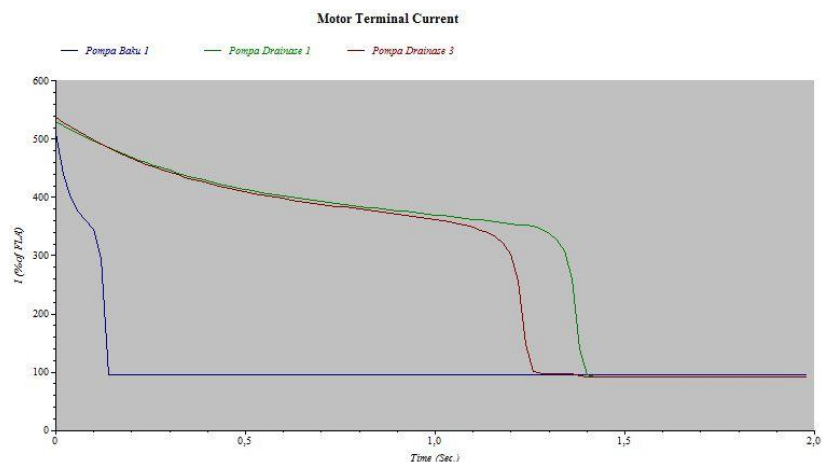

Gambar 4. Karakteristik arus 3 jenis motor dengan jenis pengasutan $\mathrm{DOL}$

Berdasarkan gambar 4 dapat dilihat arus pada pengasutan metode $D O L$ memiliki nilai yang sangat besar pada saat awal pengasutan, yang besarnya bisa mencapai 6 kali arus nominal.

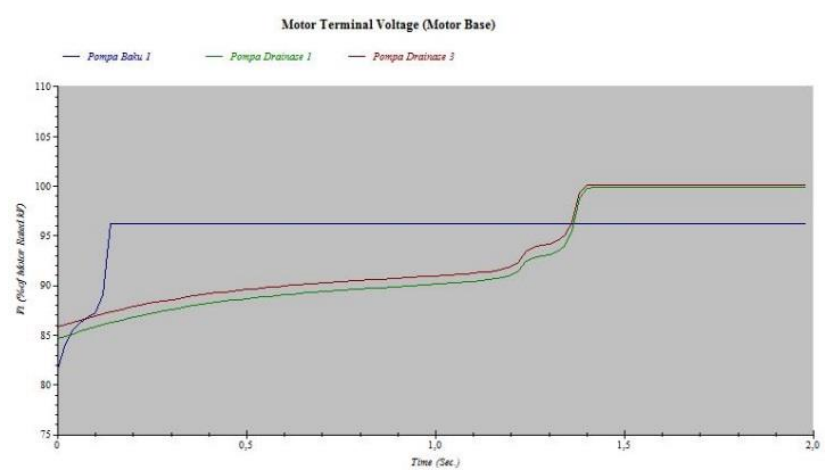

Gambar 5. Karakteristik tegangan 3 jenis motor dengan jenis pengasutan $D O L$

Pada gambar 5 dapat terlihat bahwa ketiga motor tersebut memilki nilai tegangan jatuh yang besar. Hal tersebut dikarenakan saat starting motor menyerap arus yang besar, sehingga menghasilkan tegangan jatuh yang juga bernilai besar. 


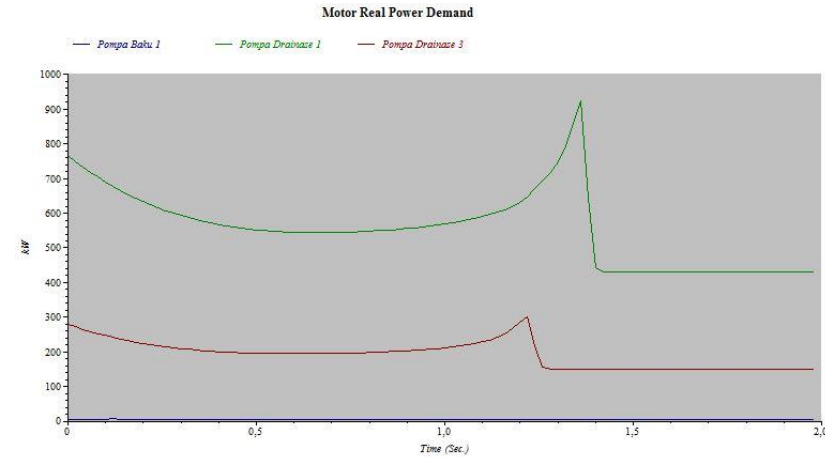

Gambar 6. Karakteristik daya 3 jenis motor dengan jenis pengasutan $D O L$

Dari gambar 6 terlihat dibutuhkan daya yang besar secara langsung pada waktu yang singkat saat pengasutan dengan metode $D O L$.

\subsection{Pengasutan Bintang-Delta}

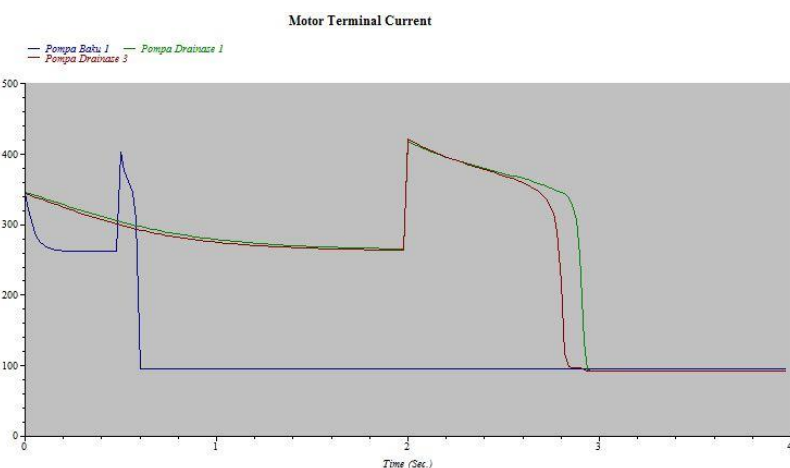

Gambar 7. Karakteristik arus 3 jenis motor dengan jenis pengasutan bintang-delta

Berdasarkan gambar 7 dapat dilihat arus pada pengasutan bintang-delta memiliki nilai yang lebih kecil dibanding saat pengasutan DOL, yaitu sekitar 4 kali lipat arus nominal.

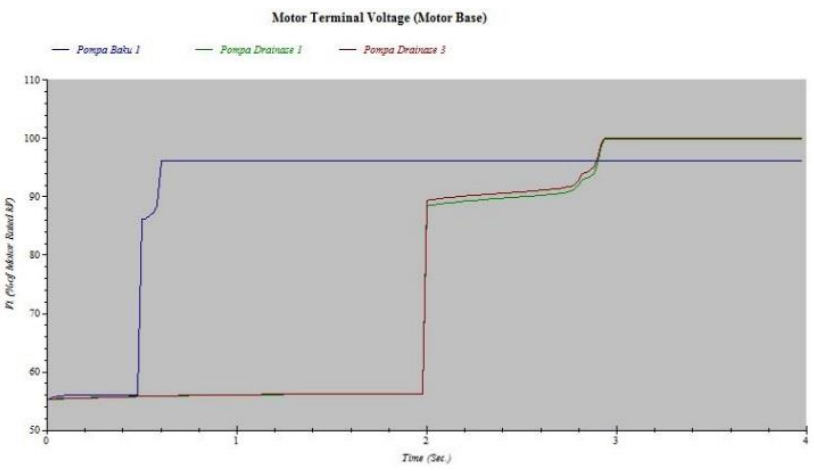

Gambar 8. Karakteristik tegangan 3 jenis motor dengan jenis pengasutan bintang-delta
Untuk tegangan pada ketiga motor berdasarkan gambar 8 memilki nilai sebesar 0,578 dari tegangan nominalnya saat dihubung bintang, hal ini didapatkan karena tegangan pada terminal motor saat hubung bintang bernilai satu per akar tiga dari tegangan nominal. Dan pada saat kembali dihubung delta terjadi lonjakan arus yang mengakibatkan terdapat tegangan jatuh yang memiliki nilai sekitar $10 \%$ dari arus nominal

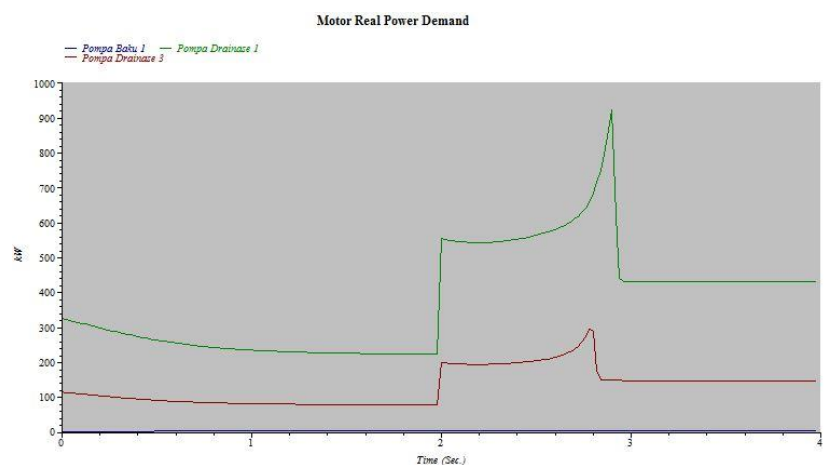

Gambar 9. Karakteristik daya 3 jenis motor dengan jenis pengasutan bintang-delta

Dari gambar 9 terlihat daya yang dibutuhkan pada saat awal pengasutan hubung bintang tidak sebesar saat pengasutan metode $D O L$, Kemudian saat dilakukan perpindahan menjadi hubung delta, motor menarik daya yang cukup besar untuk bisa bekerja stabil pada kecepatan nominalnya.

\subsection{Pengasutan Autotransformator}

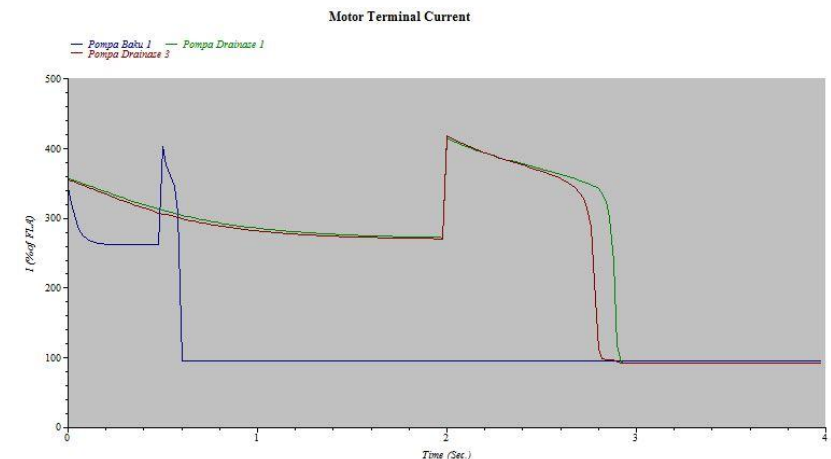

Gambar 10. Karakteristik arus 3 jenis motor dengan jenis pengasutan autotransformator

Berdasarkan gambar 10 dapat terlihat arus pada pengasutan autotransformator dengan pengaturan tap awal sebesar $60 \%$ memiliki nilai yang lebih kecil dibanding saat pengasutan $D O L$, yaitu kurang dari 4 kali lipat arus nominal. Dan saat motor sudah diberikan tegangan nominalnya besar lonjakan arusnya juga berkisar 4 kali dari arus nominalnya 


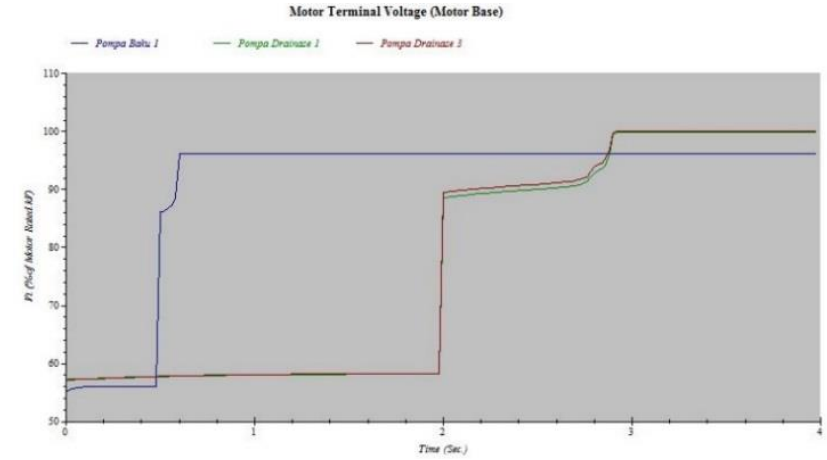

Gambar 11. Karakteristik tegangan 3 jenis motor dengan jenis pengasutan autotransformator

Untuk tegangannya berdasarkan gambar 11 memilki nilai sesuai tap tegangan sebesar $60 \%$ dan setelah dilakukan peralihan menjadi tegangan nominal, tegangan jatuh pada ketiga jenis motor memiliki nilai berkisar $10 \%$.

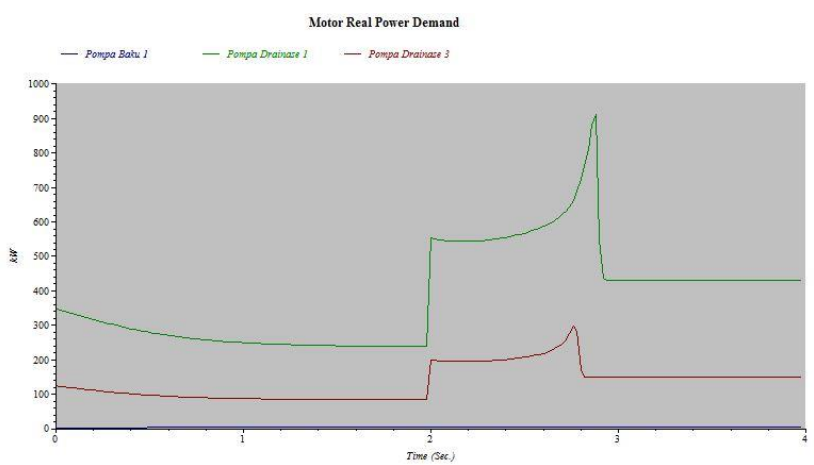

Gambar 12. Karakteristik daya 3 jenis motor dengan jenis pengasutan autotransformator

Dari gambar 12 terlihat daya yang dibutuhkan terbagi saat awal pengasutan dengan tap tegangan bernilai $60 \%$ dan kembali menarik daya saat motor sudah dihubungkan dengan tegangan nominalnya.

\subsection{Pengasutan Soft starter}

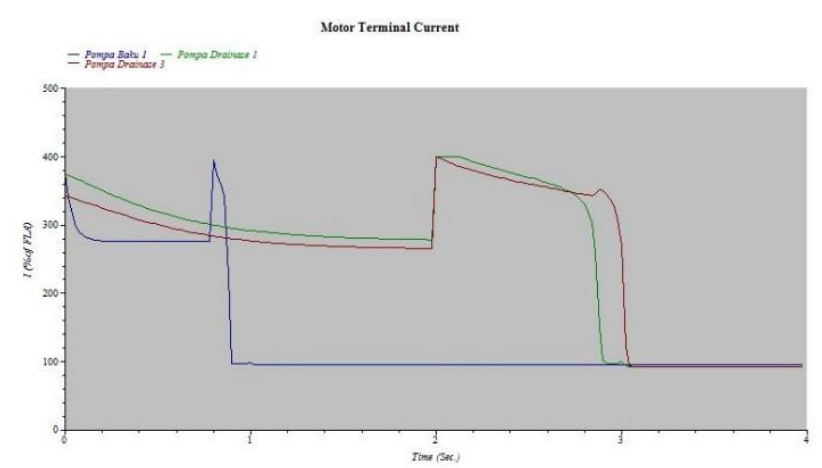

Gambar 13. Karakteristik arus 3 jenis motor dengan jenis pengasutan soft starter
Berdasarkan gambar 13 dapat dilihat arus pada pengasutan soft starter memiliki nilai yang lebih kecil dibanding saat pengasutan $D O L$, yaitu kurang dari 4 kali lipat arus nominalnya. Dan untuk lonjakan arus saat peralihan menuju tegangan nominalnya metode pengasutan soft starter memiliki bentuk dan karakteristik yang lebih halus dibandingakn dengan pengasutan bintang delta ataupun pengasutan autotransformator.

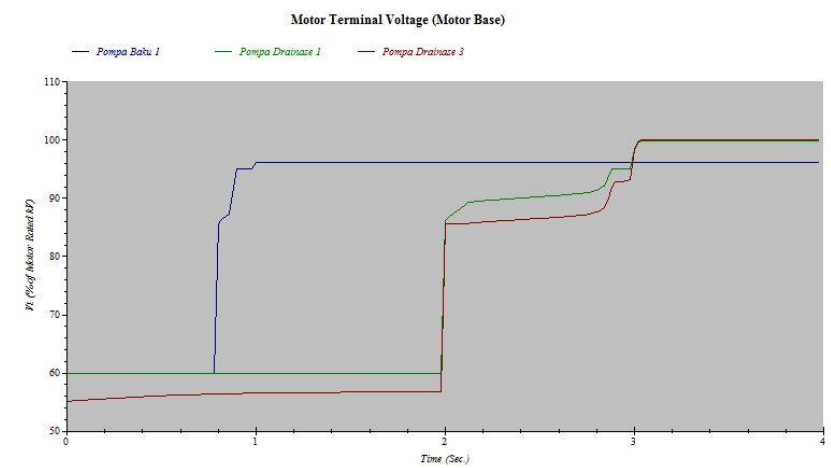

Gambar 14. Karakteristik tegangan 3 jenis motor dengan jenis pengasutan soft starter

Untuk tegangannya berdasarkan gambar 14 memilki nilai sesuai pengaturan pada soft starter sebesar $60 \%$ dan setelah dilakukan peralihan menuju tegangan nominal, tegangan jatuh memiliki nilai sekitar $10 \%$.

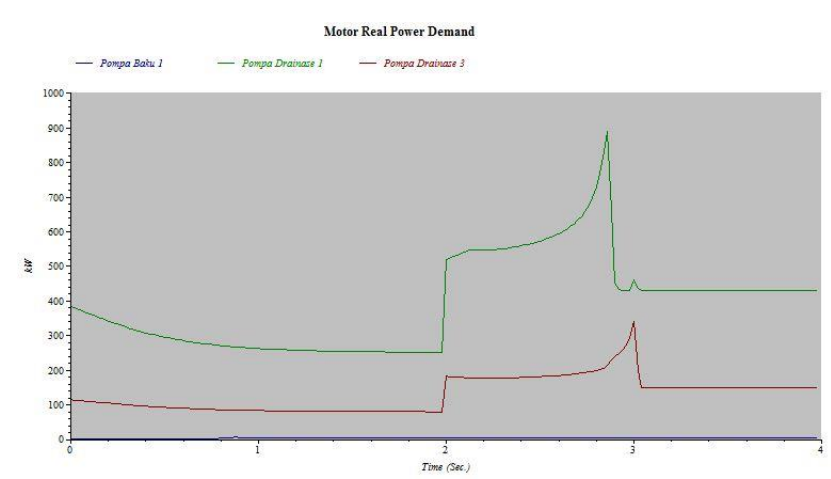

Gambar 15. Karakteristik daya 3 jenis motor dengan jenis pengasutan soft starter

Dari gambar 15 terlihat daya yang dibutuhkan terbagi saat awal starting dengan pengaturan pada soft starter sebesar $60 \%$ dan kembali menarik daya saat terminal motor sudah dihubungkan dengan tegangan nominal.

\subsection{Perbandingan Metode Pengasutan 3.5.1. Motor 3,1 KW}

Setelah meenjalankan simulasi dari keempat metode starting maka akan dibandingkan sesuai dengan parameterparameter yang telah dianalisis sebelumnya, yaitu tegangan, arus, dan juga energi motor. 
Tabel 4. Perbandingan hasil metode pengasutan pada motor 3,1 KW.

\begin{tabular}{ccccc}
\hline Parameter & DOL & $\begin{array}{c}\text { Bintang- } \\
\text { Delta }\end{array}$ & $\begin{array}{c}\text { Autotrans- } \\
\text { formator }\end{array}$ & $\begin{array}{c}\text { Soft } \\
\text { starter }\end{array}$ \\
\hline Tegangan jatuh (\%) & 17,72 & 14 & 13,9 & 9,35 \\
Arus awal (\%) & 513 & 334 & 345,47 & 375,21 \\
$\begin{array}{c}\text { Energi yang terpakai } \\
\text { (WH) }\end{array}$ & 1,018 & 0,767 & 0,785 & 0,825 \\
\hline
\end{tabular}

Dapat dilihat bahwa tegangan jatuh semua metode pengasutan masih sesuai dengan standar IEEE P3002.7/D9 yaitu tegangan jatuh maksimal $20 \%$, dengan tegangan jatuh paling besar pada pengasutan DOL sebesar $17,72 \%$ dan tegangan jatuh paling rendah pada pengasutan soft starter sebesar 9,35\%. Untuk arus awal metode $D O L$ memiliki nilai paling besar yaitu $513 \%$ dari arus nominal, sedangkan arus terkecil pada metode bintang-delta sebesar $334 \%$. Untuk energi yang terpakai saat total pengasutan selama 1 detik, metode $D O L$ menjadi yang paling borors dengan menggunakan 1,018 WH, dan bintang-delta menggunakan energi paling kecil yaitu sebesar $0,767 \mathrm{WH}$.

\subsubsection{Motor $130 \mathrm{KW}$}

Setelah menjalankan simulasi dari keempat metode starting maka akan dibandingkan sesuai dengan parameterparameter yang telah dianalisis sebelumnya, yaitu tegangan, arus, dan juga energi motor.

Tabel 5. Perbandingan hasil metode pengasutan pada motor $130 \mathrm{KW}$.

\begin{tabular}{ccccc}
\hline Parameter & DOL & $\begin{array}{c}\text { Bintang- } \\
\text { Delta }\end{array}$ & $\begin{array}{c}\text { Autotrans- } \\
\text { formator }\end{array}$ & $\begin{array}{c}\text { Soft } \\
\text { starter }\end{array}$ \\
\hline Tegangan jatuh (\%) & 12,81 & 10,1 & 10,1 & 9,35 \\
Arus awal (\%) & 545,25 & 338,95 & 351,06 & 375,21 \\
$\begin{array}{c}\text { Energi yang terpakai } \\
\text { (WH) }\end{array}$ & 0,759 & 0,578 & 0,589 & 0,604 \\
\hline
\end{tabular}

Dapat dilihat bahwa tegangan jatuh semua metode pengasutan masih sesuai dengan standar IEEE P3002.7/D9 yaitu tegangan jatuh maksimal $20 \%$, dengan tegangan jatuh paling besar pada pengasutan DOL sebesar 12,81\% dan tegangan jatuh paling rendah pada pengasutan soft starter sebesar $9,35 \%$. Untuk arus awal metode $D O L$ memiliki nilai paling besar yaitu $545,25 \%$ dari arus nominal, sedangkan arus terkecil pada metode bintangdelta sebesar $338,95 \%$. Untuk energi yang terpakai saat total pengasutan selama 4 detik, metode DOL menjadi yang paling borors dengan menggunakan $0,759 \mathrm{KWH}$, dan bintang-delta menggunakan energi paling kecil yaitu sebesar 0,578 KWH.

\subsubsection{Motor $450 \mathrm{KW}$}

Setelah menjalankan simulasi dari keempat metode starting maka akan dibandingkan sesuai dengan parameterparameter yang telah dianalisis sebelumnya, yaitu tegangan, arus, dan juga energi motor.
Tabel 6. Perbandingan hasil metode pengasutan pada motor $450 \mathrm{KW}$.

\begin{tabular}{ccccc}
\hline Parameter & DOL & $\begin{array}{c}\text { Bintang- } \\
\text { Delta }\end{array}$ & $\begin{array}{c}\text { Autotrans- } \\
\text { formator }\end{array}$ & $\begin{array}{c}\text { Soft } \\
\text { starter }\end{array}$ \\
\hline Tegangan jatuh (\%) & 12,41 & 9,25 & 9,16 & 8,79 \\
$\quad$ Arus awal (\%) & 547,79 & 348,63 & 360,81 & 375,21 \\
Energi yang terpakai & 2,213 & 1,697 & 1,727 & 1,75 \\
(WH) & & & & \\
\hline
\end{tabular}

Dapat dilihat bahwa tegangan jatuh semua metode pengasutan masih sesuai dengan standar IEEE P3002.7/D9 yaitu tegangan jatuh maksimal 20\%, dengan tegangan jatuh paling besar pada pengasutan DOL sebesar $12,41 \%$ dan tegangan jatuh paling rendah pada pengasutan soft starter sebesar $8,79 \%$. Untuk arus awal metode $D O L$ memiliki nilai paling besar yaitu $547,79 \%$ dari arus nominal, sedangkan arus terkecil pada metode bintangdelta sebesar $348,63 \%$. Untuk energi yang terpakai saat total pengasutan selama 4 detik, metode $D O L$ menjadi yang paling borors dengan menggunakan 2,213 KWH, dan bintang-delta menggunakan energi paling kecil yaitu sebesar 1,697 KWH.

\subsection{Perbandingan Biaya Investasi}

Selain memberikan perbandingan analisis teknis dari masing-masing metode pengasutan motor, pada penelitian ini diberikan juga perbandingan biaya investasi yang dibutuhkan untuk keempat jenis metode pengasutan dari ketiga jenis motor

Tabel 7. Perbandingan biaya investasi dari keempat metode pengasutan.

\begin{tabular}{lccc}
\hline $\begin{array}{c}\text { Metode } \\
\text { Pengasutan }\end{array}$ & Motor 3,1 KW & Motor 130 KW & Motor 450 KW \\
\hline $\begin{array}{l}\text { Direct On Line } \\
\text { (DOL) }\end{array}$ & Rp. 525.852 & Rp. 17.089 .035 & Rp. 75.506 .377 \\
Bintang-Delta & Rp. 2.636 .867 & Rp. 52.362.416 & Rp. 227.578.442 \\
Autotransforma & Rp. 3.474 .785 & Rp. 52.653.764 & Rp. 163.153 .420 \\
tor & Rp. 4.943.171 & Rp. 74.523.512 & Rp. 303.550.739 \\
Soft starter & & &
\end{tabular}

Pada tabel 7 dapat terlihat urutan metode pengasutan dengan biaya investasi yang paling sedikit adalah $D O L$, bintang-delta, autotransformator, dan soft starter. Hal tersebut perlu dipertimbangkan dalam pemilihan metode pengasutan yang akan digunakan agar biaya investasi menjadi efektif dan efisien.

\section{Penutup}

Berdasarkan perancangan, simulasi dan analisis yang telah dilakukan pada motor berdaya $3,1 \mathrm{KW}$ yang memiliki tegangan jatuh paling besar terdapat pada pengasutan $D O L$ sebesar $17,72 \%$ dan terendah pada pengasutan soft starter sebesar 9,35\%. Untuk arus awal metode $D O L$ memiliki nilai paling besar yaitu $513 \%$ dari arus nominal, sedangkan yang terkecil pada metode bintang-delta yaitu sebesar 
$334 \%$. Energi yang terpakai saat total pengasutan selama 1 detik, metode $D O L$ menjadi yang paling borors dengan menggunakan 1,018 WH, dan bintang-delta menggunakan energi terkecil sebesar 0,767 WH. Pada motor berdaya 130 $\mathrm{KW}$ tegangan jatuh paling besar pada pengasutan $D O L$ sebesar $12,81 \%$ dan terendah pada pengasutan soft starter sebesar $9,35 \%$. Untuk arus awal metode DOL memiliki nilai paling besar yaitu $545,25 \%$ dari arus nominal, sedangkan arus terkecil pada metode bintang-delta sebesar $338,95 \%$. Energi yang terpakai saat total pengasutan selama 4 detik, metode $D O L$ menjadi yang paling boros dengan menggunakan 0,759 KWH, dan bintang-delta menggunakan energi terkecil yaitu sebesar 0,578 KWH. Pada motor berdaya $450 \mathrm{KW}$ tegangan jatuh paling besar pada pengasutan DOL sebesar $12,41 \%$ dan yang terendah pada pengasutan soft starter sebesar $8,79 \%$. Untuk arus awal metode $D O L$ memiliki nilai paling besar yaitu $547,79 \%$ dari arus nominal, sedangkan arus terkecil pada metode bintang-delta sebesar 348,63\%. Energi yang terpakai pada motor berdaya $450 \mathrm{KW}$ saat total pengasutan selama 4 detik, metode $D O L$ menjadi yang paling borors dengan menggunakan 2,213 KWH, dan bintang-delta menggunakan energi terkecil yaitu sebesar 1,697 KWH. Tegangan jatuh dari semua metode pengasutan motor untuk ketiga jenis motor memiliki nilai yang masih sesuai dengan standar IEEE P3002.7/D9, yaitu sebesar 20\%. Untuk metode pengasutan yang direkomendasikan untuk digunakan pada motor pengendali banjir bandara Ahmad Yani adalah metode bintang-delta, dikarenakan motor tidak bekerja setiap saat. Dari segi biaya investasi juga pengasutan bintang-delta tidak memerlukan biaya yang begitu besar dibanding metode lainnya.

\section{Referensi}

[1]. Garg, Abhishek, Tomar, Arun Singh, "Starting Time Calculation for Induction Motor", Journal of Electrical \& Electronic System Vol. 4 No. 149, 2015

[2]. Youxin, Yuan, Zezhong, Xia, Yalan, Wang, "A Soft Starter of Three Phase Asynchronous Motor", IEEE, 2007

[3]. Prasetya, Andyk Probo, Abdul Hamid, Yusuf Ismail Nahkoda, "Analisis Perbandingan Sistem Pengasutan Motor Induksi 3 Fasa Sebagai Penggerak Pompa Pada Perusahaan Daerah Air Minum (PDAM) Wendit Malang", Jurnal Elektro ELTEK, Vol. 2 No. 2, Oktober 2011

[4]. Husodo, Budi Yanto, Irsyad, Habibul, “Analisa Pengasutan Motor Induksi 3 Fasa 2500 KW sebagai Penggerak Fan Pada Bag Filter", SINERGI Vol. 21, No. 3, Oktober 2017

[5]. Pinaryoga, Galih, Facta, Mochammad, Handoko, Susatyo, "Analisis Pengaruh Variasi Metode Pengasutan Motor Terhadap Tegangan Dip Yang Terjadi Pada Jaringan Kelistrikan PT Pertamina RU VI dengan Menggunakan Software ETAP 12.6", TRANSIENT, Vol. 4, No. 4, Desember 2015

[6]. Kadir, Abdul, "Mesin Tak Serempak", Penerbit Djambatan, 1981

[7]. Nurmalitawati, Aztrid, Rahardjo, Amien, "Analisis Perbandingan Arus Start Motor Induksi Berkapasitas Besar Terhadap Jatuh Tegangan Bus”, Tugas Akhir, Universitas Indonesia, 2014

[8]. https://www.academia.edu/12524051/Starting Motor_Induksi_3_Fasa, diakses pada 20 Juli 2018

[9]. Riyadi, Dwi. H, "Soft Starting Pada Motor Induksi 3 Fasa", Tugas Akhir, Universitas Diponegoro, 2011

[10]. Patil, Piyush S., Porate, K. B., "Starting Analysis of Induction Motor. A Computer Simulation by ETAP Power Station", Second International Conference on Emerging Trends in Engineering and Technology, ICETET-09

[11]. Automation solution guide, Schneider Electric, France, 2007 